\title{
Effect of low power laser irradiation on the viscosity and the hydrogen ion concentration (pH) of bio liquids in vitro
}

\author{
Ayman A. Ahmmed Tymaa Noori Alglami \\ Department of Physiology / Collage of Medicine \\ University of Mosul
}

Received

01 / 03 / 2011
Accepted

01 / 06 / 2011

\section{الماخص:}

مـ في هذا البهث لختبار تأثير ألشعة الليزر نوع هيليوم - نيون ذات القدرة المنخفضة

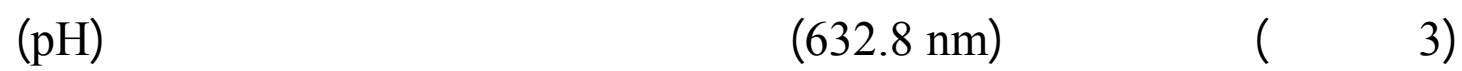

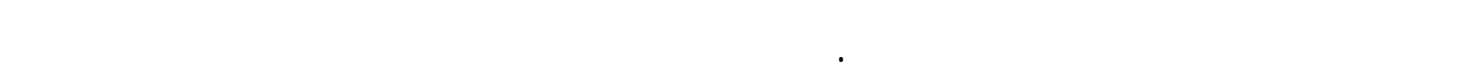
(هيليوم - نيون) وبطر بقعة (5 مليمتر) يقل من قيمة اللزوجة ويزيد من قيمة تركيز اليونات

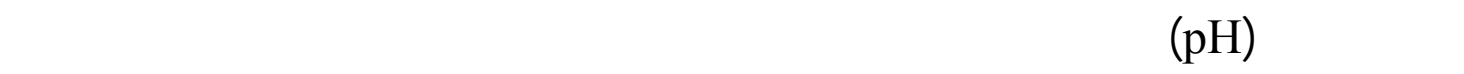

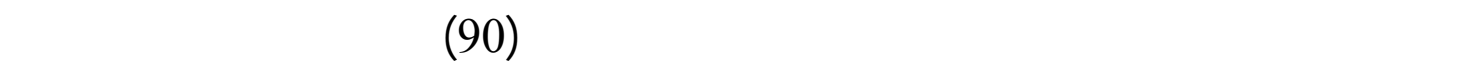

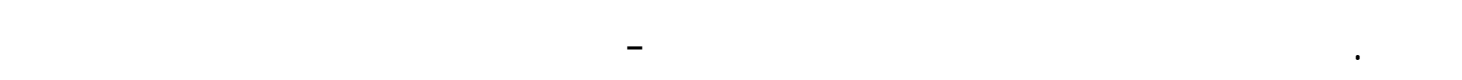

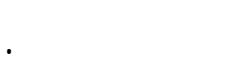

\section{Abstract:}

The effect of He-Ne laser irradiation at the wave length $632.8 \mathrm{~nm}$ on the viscosity and hydrogen ion concentration $(\mathrm{pH})$ of normal blood and ringer solution were studied in vitro. The result of the study showed that $3 \mathrm{~mW}$ laser irradiation of $5 \mathrm{~mm}$ spot diameter reduced the viscosity and increased the hydrogen ion concentration $(\mathrm{pH})$ of irradiated blood and ringer solution samples as compared to the un irradiated control value and this change was obvious at 90 minutes of exposure. Thus, the effect of He-Ne laser irradiation depends on irradiation duration.

\section{Introduction:}

The fact that low-intensity red laser radiation produces a stimulating action on various biological objects and on a living organism as a whole has been undeniable for quite a long time. A variety of studies 
both in vivo and in vitro have shown that low power laser irradiation have bio stimulating effect on human blood cells (Kruk et al,1986). Earlier study (Arora et al, 1988) has found that laser irradiation at $3.5 \mathrm{~W}$ for 30 second induced stimulating of thromboxane A2 productive in platelet which occur without any noticeable damage in the cellular structure. Other study (Brill et al, 1998) reported that blood irradiation by $\mathrm{He}-\mathrm{Ne}$ laser of $632.8 \mathrm{~nm}$ at $7 \mathrm{~mW}$ in power induced a decrease in platelet response to physiological agonist and increase in platelet cyclic.

Iijima et al, 2000 has investigated the effect of the exposure to $\mathrm{He}-\mathrm{Ne}$ laser (continuous wave, lambda $=632.8 \mathrm{~nm}, 8.5 \mathrm{~mW}$ in power) irradiation on human erythrocyte deformability. It was suggested that the irradiation of low-powered He-Ne lasers improved cytoskeletal protein activities in damaged erythrocytes.

Siposan and Adalbert, 2003 were studied the effect of a low level $\mathrm{He}-\mathrm{Ne}$ laser with doses ranged between $0-54 \mathrm{~J} / \mathrm{cm}^{2}$ on the hemoreological constants of blood. The authors observed following irradiation a lowering of the erythrocytary aggreagability (viscosity), BSR, and changes of some erythrocytary and leukocytary indices.

Further more study (Wasik et al, 2006) reported that human blood cell irradiation by $632.8 \mathrm{~nm}$ He-Ne laser of energy $0.6 \mathrm{~J} / \mathrm{cm}^{2}$ induced an increase in $\mathrm{PO}_{2}$ and $\mathrm{SaO}_{2}$ and no change in $\mathrm{PCO}_{2}$ and $\mathrm{pH}$ of irradiated samples. Recent study (X.Q. et al, 2008), under the irradiation condition of $30 \mathrm{~mW}$, the effect of $632.8 \mathrm{~nm}$ and $532 \mathrm{~nm}$ laser irradiation on rheological properties of blood were comparatively studied in vitro. It was found the laser irradiation reduced blood viscosities at different shear rates $\left(10-110 \mathrm{~S}^{-1}\right)$ for the hyper-viscosity blood samples and suggested that $532 \mathrm{~nm}$ laser irradiation demonstrated more efficient effects on modulating rheological properties than $632.8 \mathrm{~nm}$.

Although laser irradiation of power range $7 \mathrm{~mW}$ up to $3.5 \mathrm{~W}$ has established, but effect of exposure to very low power laser irradiation are not established. In present study we focused on the effect of $632.8 \mathrm{~nm}$ $\mathrm{He}-\mathrm{Ne}$ laser of $3 \mathrm{~mW}$ on the viscosity and hydrogen ion concentration $(\mathrm{pH})$ of both human blood and ringer solution.

\section{Materials and methods:}

Human blood and ringer solution being the samples of the study. 5 $\mathrm{ml}$ venous blood is taken from 10 healthy volunteers, which immediately placed in Ethylene Diamine Tetra acetic Acid tubes (EDTA) (anticoagulant) were kept in a refrigerator and used in less than 2 days. Each sample is divided into two tubes for laser irradiation and nonirradiated control.

Ringer's solution is the name given to a solution of several salts dissolved in water for the purpose of creating an isotonic solution relative to the bodily fluids of an animal. Ringer's solution typically contains 
sodium chloride, potassium chloride, calcium chloride and sodium bicarbonate, with the latter used to balance the $\mathrm{pH}$. Other additions can include chemical fuel sources for cells (Yazer et al, 2010).

The chemical composition ( $\mathrm{m} \mathrm{mol} / \mathrm{l}$ ) of the Ringer's solution used in the present study was $\mathrm{Na}+147.1, \mathrm{~K}^{+} 4.02, \mathrm{Ca}^{++} 2.25, \mathrm{Cl}^{-} 155.55$. The above ion concentrations are similar to the concentrations of human body, so we used this solution as simulated body fluid. and divided into laser irradiated and control samples. Because of the transparency of Ringer solution, a tint (red color) is added to the ringer solution to get maximum absorption of laser radiation.

\section{Laser irradiation:}

A $632.8 \mathrm{~nm}$ (red light) laser beam from a He-Ne laser was used in (college of Mosul medicine). The power of a laser on the samples was of $3 \mathrm{~mW}$ as measured by a power meter. During the experiments, the laser beam was directed to the tubes of bio liquid $(2 \mathrm{ml})$ samples with an irradiation spot of a $5 \mathrm{~mm}$ diameter. The flounce rate was $0.15 \mathrm{~mW} / \mathrm{mm}^{2}$. Blood and ringer solution samples were irradiated at room temperature $\left(17 \pm 2^{\circ} \mathrm{C}\right)$ at different time $(15,30,45,60,75$ and 90 minute).

\section{Measurement of viscosity and hydrogen ion concentration (PH):}

The bioliquid viscosity was measured by a capillary tube viscometer in (Medical physics Lab/Mosul Medical College). The viscometer was filled until the bio-liquid reached the upper mark of the reservoir of the capillary tube (Barnes et al, 1989). Free-flow time was recorded (in seconds) until the bio-liquid reached the upper mark (E) of the reservoir. The kinematic viscosity of the sample was calculated from the following formula:

$$
\eta_{1} / \eta_{2}=\mathrm{t}_{1} / \mathrm{t}_{2}
$$

where $: \eta_{1}$ is the kinematic viscosity of bio liquid.

$\eta_{2}$ is the kinematic viscosity of distilled water.

$\mathrm{t}_{1}$ : is free-flow time of bio liquid.

$\mathrm{t}_{2}$ : is free-flow time of distilled water.

The kinematic viscosity of distilled water $=1.25^{*} 10^{-3} \mathrm{~mm}^{2} / \mathrm{sec}$ at $15^{\circ} \mathrm{C}$.

For measuring hydrogen ion concentration $(\mathrm{PH})$ of bio liquid Microprocessor-based $\left(\mathrm{pH} / \mathrm{mV} /{ }^{\circ} \mathrm{C}\right)$ Bench Meters (Medical physiology $\mathrm{Lab} /$ Mosul Medical College) was used before and after laser irradiation.

$\mathrm{pH}$ is a measure of the acidity or basicity of an aqueous solution. A standard buffer solution (for $\mathrm{pH}=7.0$ ) (Robinson and Stokes, 1968) was used to calibrate the glass electrode of the $\mathrm{pH}$ meter. After the calibration is confirmed, the $\mathrm{pH}$ electrode and the temperature probe was immersed into the bio liquids samples and allow time for the electrode to stabilize. 


\section{Calculation of viscosity :}

Poiseuille's law states that the flow through a given tube depends on the pressure difference from one end to the other $\left(\mathrm{P}_{1}-\mathrm{P}_{2}\right)$, the length $\mathrm{L}$ of the tube, the radius $\mathrm{R}$ of the tube (figure 1), and the viscosity $\eta$ of the fluid, (Cameron, and Skofronic, 1992),

The viscosity $(\eta)$ can be calculated by using the following equation:

$$
\eta=\pi \mathrm{R}^{4} \Delta \mathrm{P} / 8 \mathrm{LQ}
$$

Where $\eta$ : is the viscosity of liquid

$\mathrm{R}$ : is the radius of the capillary tube

$\Delta \mathrm{P}:$ is the change in pressure at two points in capillary tube

$\mathrm{L}:$ is the high of liquid in capillary tube

$\mathrm{Q}$ : is the volume rate of flow which is equal volume of liquid $(\mathrm{V}) /$ free-flow time of liquid $(\mathrm{t})$

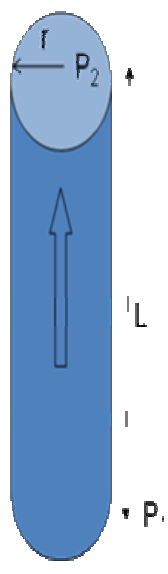

figure 1

\section{Results and discussion :}

Table (1) summarizes the results of viscosity and hydrogen ion concentration $(\mathrm{pH})$ of blood irradiated to He-Ne laser. The results of 15 minutes blood irradiation demonstrated that no changed in viscosity and $\mathrm{pH}$ value of blood were observed as compared to the control sample. While at 90 minutes of laser irradiation, there was an increased in $\mathrm{pH}$ value of blood by $2 \%$ and decreased in the blood viscosities by $7.6 \%$ over a 90 minute of exposure.

Table (1): effect of laser irradiation of blood on viscosity and $\mathrm{pH}$ values

\begin{tabular}{|c|c|c|c|}
\hline \multicolumn{2}{|c|}{ Before irradiation } & Kinematic Viscosity & pH \\
\hline \multirow[t]{7}{*}{$\begin{array}{l}\text { After } \\
\text { irradiation }\end{array}$} & $\begin{array}{c}\text { Time of } \\
\text { irradiation } / \mathrm{min}\end{array}$ & $\begin{array}{c}\text { Kinematic Viscosity } \\
\mathrm{mm}^{2} \cdot \mathrm{s}^{-1} \times 10^{-2}\end{array}$ & $\mathrm{pH}$ \\
\hline & 15 & $1.71 \pm 0.012$ & $7.4 \pm 0.01$ \\
\hline & 30 & $1.68 \pm 0.011$ & $7.42 \pm 0.01$ \\
\hline & 45 & $1.66 \pm 0.012$ & $7.45 \pm 0.01$ \\
\hline & 60 & $1.62 \pm 0.010$ & $7.48 \pm 0.01$ \\
\hline & 75 & $1.6 \pm 0.011$ & $7.51 \pm 0.01$ \\
\hline & 90 & $1.58 \pm 0.012$ & $7.55 \pm 0.01$ \\
\hline
\end{tabular}


Table (2) summarizes the results of viscosity and $\mathrm{pH}$ values of ringer solution irradiated to He-Ne laser. The results demonstrated that 60 min laser irradiations did not affect the viscosity and the value of $\mathrm{pH}$ of ringer solution as compared to the control sample. But at 90 minutes of laser irradiation there was decrease in the viscosity by $42 \%$ of the ringer solution as compared to the control sample, while the values of the effect of laser irradiation on $\mathrm{pH}$ value shows a slight increase $1.7 \%$ in $\mathrm{pH}$ value overall measurements time.

Combining the results of the effect of laser irradiation on the viscosity of blood and ringer solution is shown in figure (2), it demonstrated that irradiation to $632.8 \mathrm{~nm}$ of $3 \mathrm{~mW}$ laser can reduce the viscosities of both blood and ringer solution. This result is in agreement with other available studies on the effect of laser on the blood viscosity (Mi.Q. et al, 2008), and (Siposan and Adalbert, 2003), (see the introduction).

Table (2): effect of laser irradiation of ringer solution on viscosity and $\mathrm{pH}$ values

\begin{tabular}{|c|c|c|c|}
\hline \multicolumn{2}{|l|}{ Before irradiation } & \multirow{2}{*}{$\begin{array}{c}\text { Kinematic Viscosity } \\
\mathrm{mm}^{2} \cdot \mathrm{s}^{-1} \times 10^{3}\end{array}$} & \multirow{2}{*}{\begin{tabular}{c|} 
pH \\
$7.1 \pm 0.01$ \\
\end{tabular}} \\
\hline & & & \\
\hline \multirow[t]{7}{*}{ After irradiation } & $\begin{array}{c}\text { Time of } \\
\text { irradiation } / \mathrm{min}\end{array}$ & $\begin{array}{c}\text { Kinematic Viscosity } \\
\mathrm{mm}^{2} \cdot \mathrm{s}^{-1} \times 10^{-3}\end{array}$ & pH \\
\hline & 15 & $1.9 \pm 0.01$ & $7.1 \pm 0.01$ \\
\hline & 30 & $1.9 \pm 0.01$ & $7.1 \pm 0.01$ \\
\hline & 45 & $1.9 \pm 0.01$ & $7.14 \pm 0.01$ \\
\hline & 60 & $1.9 \pm 0.01$ & $7.16 \pm 0.01$ \\
\hline & 75 & $\overline{1.5} \pm 0.01$ & $7.19 \pm 0.01$ \\
\hline & 90 & $1.1 \pm 0.01$ & $7.22 \pm 0.01$ \\
\hline
\end{tabular}

Figure (3) show the $\mathrm{pH}$ values of irradiated blood and ringer solution, in which the $\mathrm{pH}$ values increases in all samples of blood and ringer solution. However, these changes were slight, and appeared at $60 \mathrm{~min}$ and $75 \mathrm{~min}$ of laser irradiation for blood and ringer solution respectively.

From above observation it was shown that a remarkable effect of laser irradiation on blood and ringer solution measurements were obtained at 90 minutes of irradiation. This means that the effect of $\mathrm{He}-\mathrm{Ne}$ laser irradiation depends on exposure durations.

Comparing the results of He-Ne laser irradiation effect on blood and ringer solution, its obvious that the laser irradiation was more effective on the physical properties of blood. This means that the blood absorbed photon energy more than the ringer solution and in the blood, hemoglobin $(\mathrm{Hb})$ molecules are dominating molecules, which can absorbed photons in the visible region with absorption coefficients being 
high at $632.8 \mathrm{~nm}$ (Klebanov et al, 2004). Absorbing more photons would cause more response, which seems a reasonable explanation for the dynamic effect. The photo response of blood to red laser radiation shows that the stimulating therapeutic effect of laser radiation should be attributed to absorption of red light by macromolecules that enter in formal elements of blood.

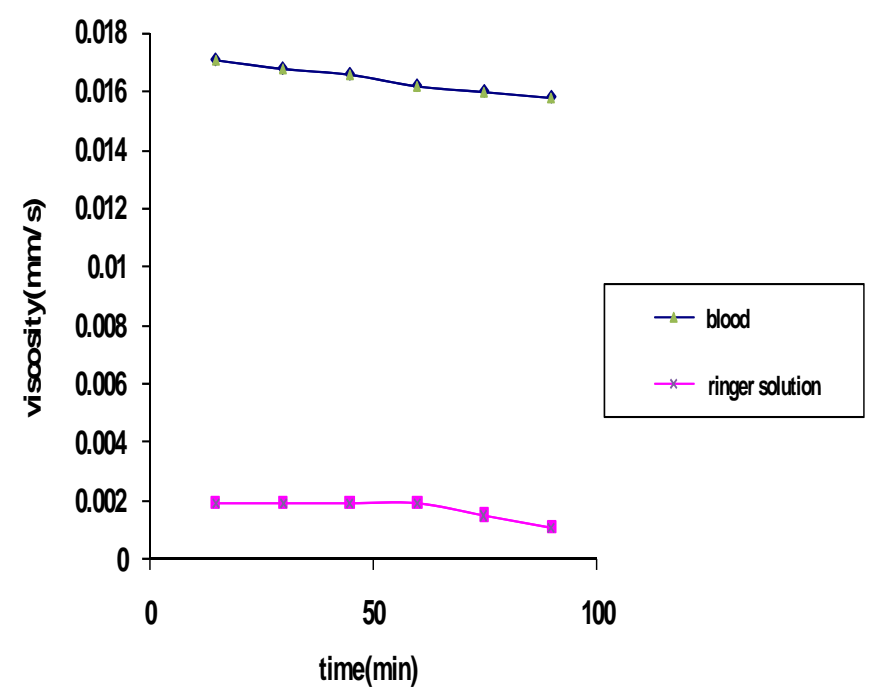

Figure (2): effect of laser irradiation of blood and ringer solution on reduced viscosity

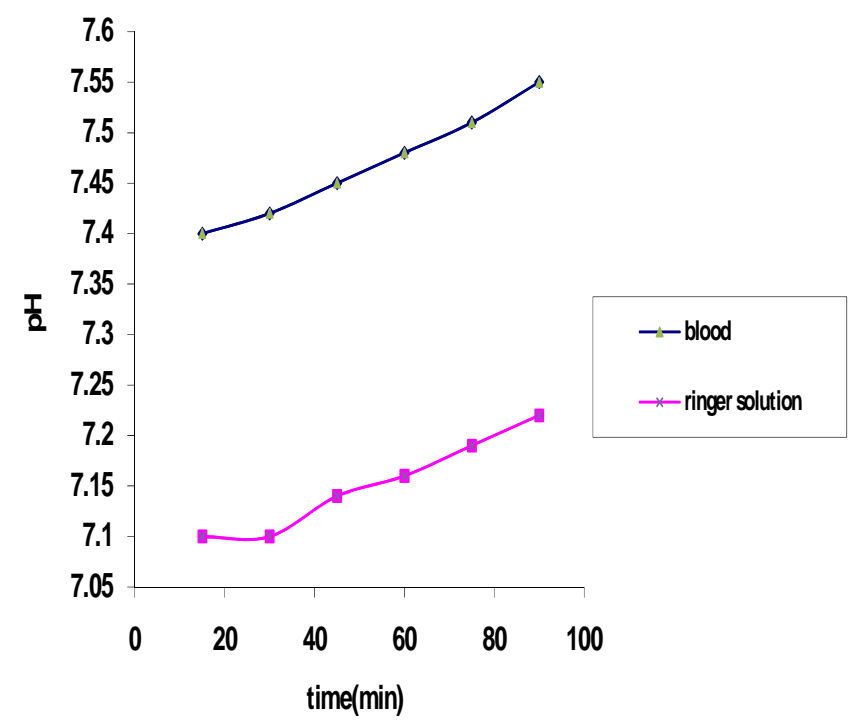

Figure (3): effect of laser irradiation of blood and ringer solution on the $\mathrm{pH}$ 


\section{Conclusion:}

Summarizing the results obtained, we can conclude that $\mathrm{He}-\mathrm{Ne}$ laser irradiation can modulate the physical properties of blood and ringer solution, including viscosity and hydrogen ion concentration $(\mathrm{pH})$. The effect of laser irradiation on blood and ringer solution was cleared at 90 minutes of irradiation, also we expect to increase the effect of laser radiation after 90 minutes of exposure.. Our results also demonstrated that the laser irradiation was faster effect on the blood than that on ringer solution. It is postulated that the hemoglobin molecules might be the target molecules under laser irradiation.

\section{References :}

1) Arora RR, Mueller HS, Sinha AK., (1988), Laser-induced stimulation of thromboxane B2 synthesis in human blood platelets: role of superoxide radicals, Lasers Surg. Med.;8(3):259-63.

2) Barnes, H.A., Hutton, J.F., and Walters, K., (1989), Viscometers for measuring shear viscosity. In An Introduction to Rheology, Rheology Series, 3, 1st ed. pp. 32-34. Elsevier Science Publishing, New York.

3) Brill AG, Shenkman B, Brill GE, Tamarin I, Dardik R, Kirichuk VF, Savion N, Varon D., (1998), Blood irradiation by He-Ne laser induces a decrease in platelet responses to physiological agonists and an increase in platelet cyclic GMP. Cell Biol Int.22(3):245-8.

4) Cameron, Jo and Skofronic, Ja, (1992), Medical physics, John Wiley and Sons, pp.166.

5) G. I. Klebanov, N. Yu. Shuraeva, Yu. V. Klimov, and N. G. Sidorina, (2004), A Comparative Analysis of the Effect of Coherent and Incoherent Red Light on Free-Radical Mechanisms for the Activation of Leucocytes. Laser Physics, Vol. 14, No. 8, pp. 11221131.

6) Iijima K, Shimoyama N, Shimoyama M, Mizuguchi T., (2000), Effect of low-power He-Ne laser on deformability of stored human erythrocytes, J Clin Laser Med Surg.;11(4):185-9.

7) Kruk, A.S., Mostovnikov, V.A., Khokhlov, I.V., (1986), Therapeutic Efficiency of Low-Intensity Laser Irradiation (Minsk: Nauka Tekh.) (in Russian).

8) Robinson, R. A., and Stokes, R. H., 1968, Electrolyte solutions, 2nd ed., rev. London, Butterworths.

9) Siposan D, Adalbert L, (2003), Experimental study of low level laser radiation effects on human blood cells. Vopr Kurortol Fizioter Lech Fiz Kult. (4):10-3.

10) Wasik M, Gorska E, Modzelewska M, Nowicki K, Jakubczak B, Demkow U., (2006), The influence of low-power helium-neon laser irradiation on function of selected peripheral blood cells. Physiol Res. 55(2):189-94. Epub 2005 May 24.

11) X.Q. Mi a,b, J.Y. Chen a,c,, Y. Cen a,b, Z.J. Liang d, L.W. Zhou a, (2008), A comparative study of 632.8 and $532 \mathrm{~nm}$ laser irradiation on some rheological factors in human blood in vitro, Journal of Photochemistry and Photobiology B: Biology 74,7-12.

12) Yazer MH, Triulzi DJ, Hassett AC, Kiss JE (2010), Cryoprecipitate prepared from plasma frozen within 24 hours after phlebotomy contains acceptable levels of fibrinogen and VIIIC, (College of American Pathologists online newsletter). 